\title{
MANAJEMEN RISIKO PERIKANAN TANGKAP (STUDI KASUS DI TENGAH PANDEMI COVID-19)
}

\author{
Atikah Nurhayatia $^{a *}$, Venda Pical ${ }^{\mathrm{b}}$, Anthon Efani ${ }^{\mathrm{c}}$ Siti Hilyaa $^{\mathrm{d}}$, Satrijo Saloko ${ }^{\mathrm{e}}$, Sutinah Made $^{\mathrm{f}}$ \\ Agus Heri Purnomo
}

\author{
${ }^{\mathrm{a}}$ FakultasPerikanan dan Ilmu Kelautan, Universitas Padjadjaran, Jalan Raya Jatinangor Km 21 \\ Provinsi Jawa Barat, Indonesia \\ ${ }^{b}$ Fakultas Perikanan dan Kelauatan, Universitas Pattimura, Jalan Raya Mr. Chr. Soplanit, Poka, Kota Ambon \\ Provinsi Maluku, Indonesia \\ 'Fakultas Perikanan dan Kelautan, Universitas Brawijaya, Jalan Veteran, Ketawanggede, Lowokwaru, Malang, \\ Provinsi Jawa Timur, Indonesia \\ ${ }^{\mathrm{d}}$ Fakultas Perikanan, Universitas Mataram, Jalan Raya Majapahit No 62, Kota Mataram \\ Provinsi Nusa Tenggara Barat, Indonesia \\ ${ }^{\mathrm{e} F a k u l t a s}$ Teknologi Pangan dan Agroindustri, Jalan Raya Unram, Gomong, Selaparang, Mataram, \\ Provinsi Nusa Tenggara Barat ,Indonesia \\ fBalai Besar Riset Sosial Ekonomi Perikanan dan Kelautan, Kementrian Kelautan dan Perikanan, \\ Jalan Pasir Putih 1, Ancol. Jakarta, Indonesia \\ *Koresponden penulis : atikah.nurhayati@unpad.ac.id
}

\begin{abstract}
Abstrak
Penyebaran wabah Coronavirusterasa dampaknya di sektor perikanan. Penyebaran Virus Corona telah membawa tantangan dan risiko baru dalam kehidupan bermasyarakat, termasuk produk perikanan tangkap. Terganggunyajalurdistribusiantarapelakuusaha dengankonsumenakibatpembatasanmobilitasmanusia yang diterapkanuntukmengatasiwabahCovid-19merupakanakarpenyebabnya. Penelitian ini bertujuan untuk menganalisis manajemen risiko perikanan tangkap di tengah pandemik Covid-19. Penelitian ini dilaksanakan pada bulan April - September 2020. Data yang digunakan yaitu data primer dan sekunder. Data primer diperoleh dengan tehnik pengambilan responden non probablity sampling kepada 50 responden pelaku usaha perikanan tangkap, dengan mengguunakan protokol kesehatan. Data sekunder diperoleh dengan menggunakan studi literatur. Alat analisis yang digunakan pada penelitian inianalisis deskriptif.Berdasarkan hasil penelitian resiko yang dihadapi oleh pelaku usaha perikanan tangkap meliputi resiko proses produksi perikanan tangkap di saat pandemik Covid - 19, risiko kerjasama hasil produksi perikanan tangkap di saat pandemik Covid -19, risiko pengambilan keputusan di saat pandemik Covid - 19, resiko pasar produk perikanan tangkap di saat pandemik. Strategi adapatasi yang dilakukan oleh pelaku usaha perikanan dengan mengoptimalkan fungsi dan peran koperasi perikanan, penguatan kelembagaan keuangan kelautan dan perikanan, strategi adaptasi pemasaran perikanan melalui sistem resi gudang.
\end{abstract}

Kata kunci: covid-19, manajemen risiko, nelayan, perikanan tangkap, strategi adaptasi

\begin{abstract}
The spread of the Coronavirus outbreak has had an impact on the fisheries sector. The spread of the Corona Virus has brought new challenges and risks in social life, including capture fisheries products. Disruption of supply chain between business actors and consumers due to restrictions on human mobility that were implemented to overcome the Covid-19 outbreak. This reserach aims to analyze the fisheries risk management case study in pandemic Covid-19. This research was conducted in April - September 2020. The data used were primary and secondary data. Primary data were obtained by applyingthe non-probability sampling techniques to 50 respondents of capture fisheries business actors, using health protocols. Secondary data were obtained throuh literature studies. The analytical tool used in this research is descriptive analysis. Based on the results of research, the risks received by capture fisheries business actors include the risk of the capture fisheries production process during the Covid-19 pandemic, the risk of collaborating with capture fisheries production during the Covid-19 pandemic, the risk of decision making during the Covid-19 pandemic, the risk of product market capture fisheries during a pandemic.Adaptation strategiesshould be undertaken by fishery business actors by optimizing the function and role of fishery cooperatives, strengthening marine and fisheries financial institutions, strategies for adapting fisheries marketing through a warehouse receiptsystem.
\end{abstract}

Keywords: covid-19, risk management, capture fisheries, fishermen, adaptation strategies 


\section{PENDAHULUAN}

Indonesia saat ini tengah melaksanakan tanggap darurat pandemic Covid-19 yang penularannya terjadi sangat cepat antar manusia. Coronavirus merupakan keluarga besar virus yang menyebabkan penyakit pada manusiadan hewan. Pada manusia biasanya menyebabkan penyakit infeksi saluran pernapasan,mulai flu biasa hingga penyakit yang serius seperti Middle East Respiratory Syndrome (MERS) dan Sindrom Pernapasan Akut Berat/ Severe Acute RespiratorySyndrome (SARS). Penyakit ini terutama menyebar di antara orang-orang melalui tetesanpernapasan dari batuk dan bersin. Virus ini dapat tetap bertahan hingga tiga haridengan plastik dan stainless steel, SARS CoV-2 dapat bertahan hingga tiga hari,ataudalam aerosol selama tiga jam. Virus ini juga telah ditemukan di feses, tetapi hinggaMaret 2020 tidak diketahui apakah penularan melalui feses mungkin, dan risikonyadiperkirakan rendah [1].

Selama masa tanggap darurat, Pemerintah Indonesia berkomitmen untuk melindungi sektor usaha, termasuk kelautan dan perikanan. Bentuk perlindungan itu, dilakukan dengan melaksanakan program penanggulangan dampak pandemic Covid-19, salah satunya pada sub sektor perikanan tangkap. Protokol kesehatan wajib diterapkan selama masa tersebut untuk pelaku usaha dan produk perikanan yang dihasilkan [2].

Pandemi wabah Covid-19 yang tengah berlangsung diperkirakan akan memicu dampak negatif bagi masyarakat, khususnya pelaku usaha perikanan tangkap yang terdiri dari nelayan, dan pemasar produk perikanan.

Berdasarkan Undang Undang No 45 Tahun 2009 Perikanan adalah semua kegiatan yang berhubungan dengan pengelolaan dan pemanfaatan sumber daya ikan dan lingkungannya mulai dari praproduksi, produksi, pengolahan sampai dengan pemasaran yang dilaksanakan dalam suatu sistem bisnis perikanan. Perikanan tangkap adalah kegiatan yang didalamnya mencakup penangkapan atau pengumpulan hewan dan tanaman air yang hidup di air laut ataupun di perairan umum secara bebas. Penangkapan adalah kegiatan untuk memperoleh ikan di perairan yang tidak dalam keadaan dibudidayakan dengan alat atau cara apapun, termasuk kegiatan yang menggunakan kapal untuk memuat, mengangkut, menyimpan, mendinginkan,menangani,mengolah dan/atau mengawetkannya [3].

Perikanan tangkap dalam pelaksanaannya tidak lepas dari peran nelayan, tanpa adanya nelayan sektor perikanan tangkap tidak akan termanfaatkan. Nelayan adalah orang yang mata pencahariannya melakukan penangkapan ikan untuk memenuhi kebutuhan hidup seharihari.Pemasaran perikanan tangkap didefinisikan sebagai kinerja dari semua kegiatan usaha yang terlibat dalam aliran produk input produksi yang meliputi hasil perikanan tangkap dalam bentuk segar sampai berada di tangan konsumen akhir[4].

Pada masa pandemik Covid-19, untuk mencegah dampak yang lebih besar terhadap kehidupan bermasyarakat, pemerintah Indonesia menyiapkan beragam langkah untuk menjalankan protokol kesehatan Covid-19. Wabah virus Corona berdampak pada pemasaran perikanan tangkap, dimana harga ikan mengalami penurunan hingga 50 \%.Penurunan harga ini dikarenakan adanya pembatasan sosial berskala besar (PSBB) yang menyebabkan mata rantai dari pelaku usaha perikanan mengalami keterpurukan [5].

Dampak pandemi Covid-19 yang paling dirasakan oleh pelaku usaha perikanan tangkap seperti nelayan dan pemasar produk perikanan tangkap yaitu harga ikan yang mengalami penurunan, biaya operasional yang semakin tinggi, hasil perikanan tangkap yang sulit untuk dijual karena terbatasnya akses transportasi dan physical distancingserta karantina wilayah di beberapa daerah sehingga banyak pasar dan restoran-restoran yang tutup atau membatasi waktu operasionalnya, yang mengakibatkan turunnya permintaan produk perikanan tangkap.

Perikanan tangkap yang diatur dalam Wilayah Pengelolaan Perikanan Negara Republik Indonesia, yang selanjutnya disebut WPPNRI, merupakan wilayah pengelolaan perikanan tangkap yang meliputi perairan pedalaman, perairan kepulauan, laut teritorial, zona tambahan, dan zona ekonomi eksklusif Indonesia

Produk perikanan tangkap yang dihasilkan memiliki karakteristik mudah 
busukdan bersifat musiman, sehingga diperlukan suatu sistem manajemen risiko dalam melakukan pemasaran produk perikanan tangkap. [6].

Risiko merupakan probalilitas potensi yang menimbulkan kerugian atau suatu keadaan yang tidak pasti yang dihadapi seseorang atau perusahaan dan dapat memberikan dampak yang merugikan [7].

Usaha perikanan tangkap dihadapkan pada risiko dan ketidakpastian secara teknis dan non teknis. Dari sisi produksi, risiko yang dihadapi oleh nelayan adalah hasil tangkapan yang sangat bervariasi Hal tersebut merupakan akibat dari ketergantungan usaha penangkapan terhadap kondisi alam dan cuaca atau musim. [8].

Pekerjaan sebagai nelayan dihadapkan padafaktor ketidakpastian yang meningkat dari waktu ke waktu baik faktor alam maupun ekonomi. Faktor alam di antaranya faktor musim yang sulit diprediksi sedangkan fakor ekonomi adalah semakin tingginya biaya melaut hasil tangkapan yang cenderung menurun dan fluktuasi harga ikan[9].Berdasarkan urian di atas perlu dilakukan penelitian mengenai manajemen risiko pemasaran perikanan tangkap di tengah pandemik Covid-19.

\section{METODE}

\section{Lokasi Penelitian}

Penelitian ini dilaksanakan di Indonesia dengan memfokuskan di beberapa sentra produksi perikanan tangkap yang terwakili, yaitu Jawa Barat, Jawa Timur, Sulawesi Selatan, Maluku dan Nusa Tenggara Timur. Waktu penelitian dilaksankan pada bulan April - September 2020.

\section{Metode Pengumpulan Data}

Data yang digunakan yaitu data primer dan sekunder. Data primer diperoleh dengan tehnik pengambilan responden non probablity sampling kepada 50 responden pelaku usaha nelayan yang melakukan kegiatan penangkapan ikan one day fishing dan pemasar perikanantangkap, dengan mengguunakan protokol kesehatan. Data sekunder diperoleh dengan menggunakan studi literatur.

\section{Metode Analisis Data}

Alat analisis yang digunakan pada penelitian ini analisis deskriptif dengan menggunakan probabilitas.[10]. Permasalahan yang dihadapi dalam melakukan estimasi resiko proses produksi perikanan tangkap di saat pandemik Covid - 19, risiko kerjasama hasil produksi perikanan tangkap di saat pandemik Covid -19 , risiko pengambilan keputusan di saat pandemi Covid - 19, resiko pasar produk perikanan tangkap di saat pandemi.

\section{HASIL DAN PEMBAHASAN}

\section{Krakteristik Lokasi Penelitian}

Penelitian ini dilaksanakan di Indonesia dengan memfokuskan di beberapa sentra produksi perikanan tangkap yang terwakili, yaitu Jawa Barat, Jawa Timur, Sulawesi Selatan, Maluku dan Nusa Tenggara Timur

Kegiatan penangkapan ikan yang dilakukan oleh nelayan tradisional, dengan menggunakan jenis armada ukuran $<5$ GT yang kegiatan operasinya bersifat harian (one day fishing). Kegiatan penangkapan ikan dilakukan berkisar antara enam sampai tujuh jam dalam satu trip, dengan menggunakan 1-3 orang ABK (anak buah kapal).

Berdasarkan hasil penelitian biaya operasional yang diperlukan untuk kegiatan melaut, yaitu berkisar antara Rp. 500.000 Rp. 800.000 per trip. Biaya tersebut digunakan untuk pembelian solar, umpan, es balok dan bekal melaut. Jenis ikan yang tertangkap adalah ikan pelagis kecil dan demersal seperti ikan kembung, layang, kepiting, udang dan rajungan. Jenis alat tangkap yang digunakan oleh nelayan cukup beragam, seperti pukat plastik, kikis, gill net, lampara, pancing rawai, jaring udang, togo dan jaring tiga lapis. Biasanya dalam satu kapal mempunyai dua sampai tiga jenis alat tangkap.

Terkait dengan kalender musim penangkapan, terdapat dua musim yaitu musim puncak dan paceklik. Kalender musim akan mempengaruhi tinggi rendahnya pendapatan seorang nelayan. Pada musim puncak, jumlah tangkapan akan berlimpah 
sedangkan pada musim paceklik jumlah tangkapan akan jauh menurun dengan drastis.

Perikanan tangkap mengalami kesulitan dalam mendistribusikan bahan baku melalui transportasi darat, laut maupun udara akibat Covid-19. Nelayan juga mengurangi waktu melaut dikarenakan ada pembatasan di Pelabuhan yaitu dilakukan karantina terlebih dahulu sebelum bersandar di darmaga atau pangkalan pendaratan ikan serta kurangnya penyerapan hasil tangkapan dari pabrik atau rumah olahan produk perikanan.

Karakteristik responden yang dilihat dalam penelitian ini meliputi umur, tingkat pendidikan, dan tanggungan keluarga.Berdasarkan hasil penelitian di lapangan $70 \%$ usia produktif. Usia mempengaruhi kemampuan kerja seseorang, karena kemampuan kerja produktif akan terus menurun dengan semakin bertambahnya usia seseorang, sedangkan tingkat pendidikan akan berpengaruh terhadap pola dan cara berpikir seseorang, yang erat hubungannya dengan keberhasilan pengembangan usaha yang dilakukan, baik yang diperoleh melalui jenjang pendidikan formal maupun informal[11]. Berdasarkan hasil penelitian di lapangan tingkat pendidikan responden yang mengenyam pendidikan Sekolah Dasar $50 \%$, Sekolah Menengah Pertama sebesar $30 \%$, dan Sekolah Menengah Atas sebesar $20 \%$.

Berdasarkan penelitian di lapangan tanggungan keluarga responden $60 \%$ berada pada kisaran > 5 anggota keluarga. Jumlah tanggungan keluarga adalah jumlah anggota keluarga yang menjadi tanggungan dari rumah tangga tesebut, baik itu saudara kandung maupun saudara bukan kandung yang tinggal satu rumah khususnya yang belum bekerja.

Peningkatan penghasilan keluarga nelayan berdasarkan penelitian di lapangan digunakan untuk menambah jumlah anaknya, sebaiknya peningkatan penghasilan digunakan untuk menambah kualitas anaknya melalui pendidikan. Sehingga ada kesempatan bagi anak nelayan untuk memperoleh pendidikan yang lebih baik dari pada orang tuanya di masa depan.
Tabel 1 Sub variabel risiko produksi perikanan tangkap di saat pandemik Covid - 19

\begin{tabular}{llc}
\hline Variabel & Sub Variabel & Probabilitas \\
\hline Resiko & Faktor iklim & $35 \%$ \\
proses & Kapal untuk & $17 \%$ \\
produksi & melaut & \\
perikanan & Alat tangkap & $13 \%$ \\
tangkap di & perikanan & \\
saat & Ketidakpastian \\
pandemi & hasil perikanan & $25 \%$ \\
Covid - & tangkap & \\
19 & $\begin{array}{l}\text { Target spesies } \\
\text { perikanan } \\
\text { tangkap }\end{array}$ & $10 \%$ \\
& & \\
\hline
\end{tabular}

Berdasarkan hasil penelitian di lapangan probabilitas resiko proses produksi perikanan tangkap di saat pandemi Covid-19 meliputi: faktor iklim dengan probabilitas mencapai 35 $\%$ dimana perubahan iklim mengakibatkan variabilitas iklim seperti frekuensi, intensitas, durasi, dan waktu peristiwa cuaca dan iklim yang ekstrim [12]. Perubahan iklim akan memperbesar nilai variabilitas iklim dan mempercepat periode terjadinya variabilitas iklim tersebut. Variabilitas pancaroba musiman dan tahunan di Indonesia dipengaruhi oleh monsun danEl NinoSouthern Oscillation(ENSO) [14]. Monsun mempengaruhi iklim Indonesia melalui pergerakan titik kulminasi matahari yang mengakibatkan Indonesia mengalami musim hujan dan musim kemarau. Risiko proses produksi perikanan tangkap di saat pandemi Covid - 19terkait perubahan iklim adalah adanya interaksi bahaya yang berkaitan dengan iklim.

Berdasarkan hasil penelitian di lapangan probabilitas resiko proses produksi perikanan tangkap di saat pandemi Covid - 19 meliputi: faktor kapal untuk melaut sebesar $17 \%$, ditentukan oleh klasifikasi nelayan. Nelayan kecil adalah nelayan yang melakukan aktivitas penangkapan Ikan untuk memenuhi kebutuhan hidup sehari-hari, baik yang tidak menggunakan kapal penangkap Ikan maupun yang menggunakan kapal penangkap ikan berukuran paling besar 10 (sepuluh) gros ton (GT) dan nelayan tradisional adalah nelayan yang melakukan aktivitas penangkapan ikan di perairan yang merupakan hak perikanan tradisional yang telah dimanfaatkan secara turun-temurun sesuai dengan budaya dan kearifan lokal [14]. 
Berdasarkan hasil penelitian di lapangan probabilitas resiko proses produksi perikanan tangkap di saat pandemi Covid - 19 meliputi: Alat Penangkapan Ikan sebesar $13 \%$, adalah sarana dan perlengkapan atau benda-benda lainnya yang dipergunakan untuk menangkap ikan [15].

Berdasarkan hasil penelitian di lapangan probabilitas resiko proses produksi perikanan tangkap di saat pandemi Covid-19 meliputi: ketidakpastian hasil perikanan tangkap sebesar $25 \%$ serta Target spesies perikanan tangkap sebesar $10 \%$.

Tabel 2. Sub variabel risiko kerjasama hasil produksi perikanan tangkap di saat pandemi Covid - 19.

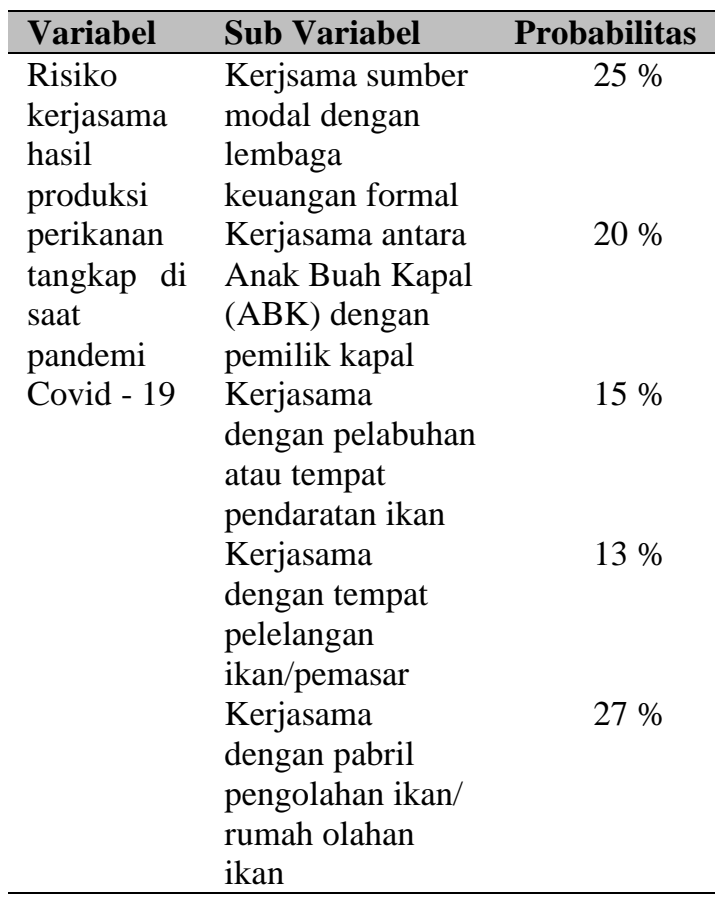

Berdasarkan hasil penelitian di lapangan probabilitasrisiko kerjasama hasil produksi perikanan tangkap di saat pandemi Covid -19 meliputi : kerjsama sumber modal dengan lembaga keuangan formal sebesar $25 \%$, kebijakan pemerintah pusat dan daerah mengenai tangkap darurat bencana dengan memberikan bantuan modal usaha bagi nelayan yang terkena dampak Covid-19 seperti perawatan armada penangkapan ikan, alat tangkap, bahan bakar untuk melaut, kondisi ini meringankan beban kehidupan nelayan di tengah dan pasca pandemi Covid$19[16]$.
Berdasarkan hasil penelitian di lapangan probabilitasrisiko kerjasama hasil produksi perikanan tangkap di saat pandemi Covid-19 meliputi: kerjasama antara Anak Buah Kapal (ABK) dengan pemilik kapal sebesar $20 \%$, kerjasama dengan pelabuhan atau tempat pendaratan ikan sebesar $15 \%$, kerjasama dengan tempat pelelangan ikan/pemasar $13 \%$, kerjasama dengan pabrik pengolahan ikan/ rumah olahan ikan

Tabel 3 Sub variabel risiko pengambilan keputusan di saat pandemi Covid - 19

\begin{tabular}{|c|c|c|}
\hline Variabel & Sub Variabel & Probabilitas \\
\hline \multirow[t]{5}{*}{ aha } & $\begin{array}{l}\text { Risiko kesehatan } \\
\text { melakukan aktivitas } \\
\text { melaut tanpa } \\
\text { menggunakan } \\
\text { protokol kesehatan }\end{array}$ & $30 \%$ \\
\hline & $\begin{array}{l}\text { Risiko kesehatan } \\
\text { melakukan aktivitas } \\
\text { di laut } \\
\text { menggunakan } \\
\text { protokol kesehatan }\end{array}$ & $10 \%$ \\
\hline & $\begin{array}{l}\text { Risiko kesehatan } \\
\text { melakukan aktivitas } \\
\text { pelelangan ikan } \\
\text { tanpa menggunakan } \\
\text { protokol kesehatan }\end{array}$ & $20 \%$ \\
\hline & $\begin{array}{l}\text { Risiko kesehatan } \\
\text { melakukan aktivitas } \\
\text { pelelangan ikan } \\
\text { menggunakan } \\
\text { protokol kesehatan }\end{array}$ & $15 \%$ \\
\hline & $\begin{array}{l}\text { Rsiko kesehatan } \\
\text { melakukan } \\
\text { interaksi dengan } \\
\text { pelaku usaha } \\
\text { lainnya } \\
\text { menggunakan } \\
\text { protokol kesehatan }\end{array}$ & $25 \%$ \\
\hline
\end{tabular}

Berdasarkan hasil penelitian di lapangan probabilitas risiko pengambilan keputusan di saat pandemi Covid-19, meliputi : risiko kesehatan melakukan aktivitas melaut tanpa menggunakan protokol kesehatan sebesar 30 $\%$, nelayan sering tidak menggunakan protokol kesehatan pada saat melaut, namun masing masing nelayan tetap mengusahan untuk menjaga jarak antara yang satu dengan yang lainnya. Risiko kesehatan melakukan aktivitas di laut menggunakan protokol kesehatan memiliki nilai probabilitas sebesar $10 \%$. Risiko kesehatan melakukan aktivitas 
pelelangan ikan tidak menggunakan protokol kesehatan sebesar $20 \%$. Probabilitas risiko kesehatan melakukan aktivitas pelelangan ikan menggunakan protokol kesehatan sebesar $15 \%$ dan probabilitas risiko kesehatan ketika melakukan interaksi dengan pelaku usaha lainnya menggunakan protokol kesehatan sebesar $25 \%$.

Protokol kesehatan ini dilakukan sebagai upaya pencegahan dan pengendalian Covid-19 di tempat kerja dan fasilitas umum dengan memperhatikan aspek perlindungan kesehatan individu dan masyarakatserta titik-titik kritis dalam perlindungan kesehatan masyarakat, yang melibatkan pengelola,penyelenggara,atau penanggung jawab tempat dan fasilitas umum serta masyarakat pengguna.

Masyarakat nelayan dan pelaku usaha perikanan serta masyarakat pada umumnya harus dapat beraktivitas kembali dalam situasi pandemi Covid-19 dengan beradaptasi pada kebiasaan baru $(\mathrm{AKB})$ yang lebih sehat, lebih bersih, dan lebih taat, yang dilaksanakan oleh seluruh komponen yang ada di masyarakat serta memberdayakan semua sumber daya yang ada. Peran masyarakat untuk dapat memutus mata rantai penularan Covid-19 harus dilakukan dengan menerapkan protokol kesehatan [17].

Tabel 4. Sub variabel risiko pasar produk perikanan tangkap di saat pandemi

\begin{tabular}{|c|c|c|}
\hline Variabel & Sub Variabel & Probabilitas \\
\hline \multirow{5}{*}{$\begin{array}{l}\text { Resiko } \\
\text { pasar } \\
\text { produk } \\
\text { perikanan } \\
\text { tangkap di } \\
\text { saat } \\
\text { pandemi } \\
\text { Covid - } 19\end{array}$} & $\begin{array}{l}\text { Jalur distribusi } \\
\text { mengalami kendala } \\
\text { karena adanya } \\
\text { Pembatasan Sosial } \\
\text { Berskakla Besar } \\
\text { (PSBB) }\end{array}$ & $30 \%$ \\
\hline & $\begin{array}{l}\text { Penurunan } \\
\text { permintaan produk } \\
\text { perikanan tangkap } \\
\text { untuk konsumen } \\
\text { akhir/ restoran/ cafe }\end{array}$ & $20 \%$ \\
\hline & $\begin{array}{l}\text { Penurunan } \\
\text { permintaan produk } \\
\text { perikanan tangkap } \\
\text { untuk pasar lokal }\end{array}$ & $5 \%$ \\
\hline & $\begin{array}{l}\text { Penurunan } \\
\text { permintaan produk } \\
\text { perikanan tangkap } \\
\text { untuk pasar } \\
\text { domestik }\end{array}$ & $15 \%$ \\
\hline & Penurunana & $30 \%$ \\
\hline
\end{tabular}

permintaan produk

perikanan tangkap

untuk pasar ekspor

Berdasarkan hasil penelitian di lapangan probabilitas risiko pasar produk perikanan tangkap di saat pandemikCovid - 19, meliputi: jalur distribusi mengalami kendala karena adanya Pembatasan Sosial Berskala Besar (PSBB) sebesar $30 \%$. Pembatasan Sosial Berskala Besar merupakan salah satu kebijakan yang dilakukan oleh pemerintah pusat dan daerah dengan pembatasan kegiatan tertentu penduduk dalam suatu wilayah yang diduga terinfeksi Covid-19 sedemikian rupa untuk mencegah kemungkinan penyebaran Covid-19[19].

Penurunan Permintaan produk perikanan tangkap untuk konsumen akhir/ restoran/ cafeseafood memiliki nilai probabilitas sebesar $20 \%$, dengan adanya peraturan daerah mengenai usaha restoran dan cafe termasuk restoran seafood, dengan jam operasional yang dibatasi lebih cepat dari kondisi normal serta harus menerapkan standar pelayanan dengan protokol kesehatan dan diarahkan untuk dibawa pulang secara langsung (take away), melalui pemesanan secara daring.

Penurunan Permintaan produk perikanan tangkap untuk pasar lokal dengan probabilitas sebesar $5 \%$, penurunan permintaan produk perikanan tangkap untuk pasar domestik sebesar $15 \%$, sedangkan permintaan dari luar negeri menurun sebanyak $30 \%$. Kondisi tersebut menyebabkan gudang penyimpanan penuh sehingga perusahaan mengurangi suplay bahan baku. Pembatasan transportasi dan pekerja di pabrik juga mengurangi kapasitas penyerapan ikan dari nelayan dan pengurangan output produksi perikanan tangkap. Penyerapan pasar dalam negeri dan ekspor yang menurun, hal ini karena terhambatnya jalur distribusi bahan baku yang terbatas, karena adanya kebijakan pembatasan sosial berskala besar.

\section{Strategi Adaptasi Nelayan Pra dan Pasca Pandemik Covid- 19 (Adaptasi Kebiasaan Baru/ Normal Baru).}

Strategi untuk mengurangi resiko atau dampak Covid-19 pada sektor perikanan. Salah satunya adalah dengan menerbitkan 
Surat Edaran Kementrian Kelautan dan Perikanan tentang alih muatan pada kapal perikanan. KKP juga telah mengusulkan perluasan cakupan Peraturan Menteri Keuangan No. 23 Tahun 2020 tentang Insentif Pajak untuk Wajib Pajak Terdampak Wabah Virus Corona, dengan memasukkan kelautan dan perikanan[19].

Optimalisasi peran koperasi nelayan dengan melakukan penyebaran bantuan sosial yang diberikan oleh pemerintah pusat dan daerah serta pemanfaatan bantuan berupa cold storagekemudian prosesnya ikanhasil tangkapan dibekukan dengan Air Blast Freezer (ABF), dan disimpan dalam cold storage. Koperasi nelayan diharapkan untuk tetap melakukan aktifitas jual beli hasil perikanan tangkap,pengolahan, pembekuan dan penyimpanan ikan

Industri olah perikanan tangkap harus mendapatkan perhatian dari pemerintah pusat dan daerah karena mampu menyerap tenaga kerja yang berada di kawasan pesisir, yang sebagian besar penduduknya bermatapenceharian sebagai nelayan. Industri olahan perikanan tangkap melakukan pembelian hasil tangkapan dari nelayan yang berskala kecil. Akses terhadap perizinan usaha perikanan tangkap. Surat Izin Usaha Perikanan yang selanjutnya disebut SIUP merupakan izin secara tertulis yang harus dimiliki oleh perusahaan perikanan untuk melakukan usaha perikanan dan Surat Izin Penangkapan Ikan yang selanjutnya disebut SIPI merupakan izin tertulis yang harus dimiliki oleh setiap kapal perikanan untuk melakukan penangkapan ikan yang merupakan bagian yang tidak terpisahkan dari SIUP [20].

Strategi adaptasi terhadap sumber modal dalam melakukan aktivitas perikanan tangkap, pemerintah memfasilitasi dengan melakukan kerjasama dengan lembaga perbankan dan lembaga penyedia modal usaha untuk memberikan akses permodalan kepada nelayan.

Lembaga Pengelola Modal Usaha Kelautan dan Perikanan, yang selanjutnya disingkat LPMUKP, merupakan unit organisasi non struktural yang berada di bawah Kementrian Kelautan dan Perikanan, yang mempunyai tugas melaksanakan pengelolaan dana bergulir dan pendampingan bagi pelaku usaha mikro, kecil, dan menengah sektor kelautan dan perikanan [21].

Strategi adapatsi terhadap pasar domestik perikanan yang mengalami penurunan permintaan akibat terjadinya penurunan pendapatan masyarakat, terjadinya Pemutusan Hubungan Kerja (PHK) yang menyebabkan daya beli masyarakat menjadi menurun, sehingga dilakukan strategi subsitusi terhadap barang yang diperjualbelikan untuk memenuhi kebutuhan pangan, sandang dan papan.

Strategi adaptasi sistem pasar domestik dan ekspor salah satu solusinya dengan menerapkan Sistem Resi Gudang yang selanjutnya disingkat SRG adalah kegiatan yang berkaitan dengan penerbitan, pengalihan, penjaminan, dan penyelesaian transaksi resi gudang.Resi gudang adalah dokumen bukti kepemilikan atas barang yang disimpan di Gudang yang diterbitkan oleh Pengelola Gudang.Barang adalah setiap benda bergerak yang dapat disimpan dalam jangka waktu tertentu dan diperdagangkan secara umum termasuk produk perikanan [23].

Sistem resi gudang ini harus disosilisasikan kepada para pelaku usaha perikanan, khususnya bagi nelayan dilakukan melalui proses penyuluhan dan pendampingan usaha. Strategi adaptasi sistem resi gudang diharapkan mampu menstabilkan harga produk perikanan dan menjaga kontinuitas produk perikanan dari hulu sampai ke hilir industri usaha mikro kecil dan menengah kelautan dan perikanan.

\section{KESIMPULAN}

Berdasarkan hasil penelitian dapat disimpulkan kondisi pelaku usaha perikanan, khususnya nelayan mengalami risiko usaha di tengah pandemi Covid-19, sehingga harus dilakukan strategi adapatasi oleh pelaku usaha perikanan dengan mengoptimalkan fungsi dan peran koperasi perikanan, penguatan kelembagaan keuangan kelautan dan perikanan, strategi adaptasi pemasaran perikanan melalui sistem resi gudang

\section{UCAPAN TERIMA KASIH}

Ucapan terimakasih disampaikan kepada responden dan pelaku usaha perikanan yang telah memberikan informasi mengenai kondisi eksisting di lapangan serta kolaborasi dan 
kontribusi dari para peneliti lintas Universitas di Indonesia.

\section{DAFTAR PUSTAKA}

[1]. Van Doremalen N, Bushmaker T, Morris DH, Holbrook MG, Gamble A, Williamson $\mathrm{BN}$, et al. "Aerosol and Surface Stability of SARS-CoV-2 as Compared with SARS-CoV-1". The New England Journal of Medicine. Massachusetts Medical Society. doi:10.1056/nejmc2004973. PMID 32182409.(March 2020)

[2]. Keputusan Menteri Kelautan dan Perikanan Republik Indonesia. Nomor 27/KEPMEN-KP/2020 Tentang Satuan Tugas Pencegahan dan Penanggulangan Penyebaran Corona Virus Disease 2019 (COVID-19) Kementrian Kelautan dan Perikanan.

[3]. Undang - Undang Republik Indonesia. Nomor 45 Tahun 2009. Tentang Perikanan.

[4]. Atikah Nurhayati, Asep Agus Handaka, Iwang Gumilar. Manajemen Pemasaran Produk Perikanan. Unpad Press. 143 Hal. 2018.

[5]. Direktorat Jenderal Pencegahan dan Pengendalian Penyakit.2020. Pedoman Kesiapsiagaan Menghadapai Corona Virus Disease 2019 (COVID 19) hal 89.

[6]. A Nurhayati., I.Aisah dan A.K. Supriatna. Promoting Innovative Business In The Fishery Sector In West Java, Indonesia. IOP Conf. Series: Earth and Environmental Science 137.2018

[7]. Kountur, R.. Manajemen Risiko. Jakarta. Abdi Tandur. Halaman 1-37. 2006.

[8]. Imelda. Analisis Risiko Pada Usaha Penangkapan Kepiting Bakau di Kecamatan Sungai Kunyit Kabupaten Pontianak. Jurnal Sosial Ekonomi
Pertanian Volume 1 Nomor 1. April 2012. hlm 75-95.2012.

[9]. Nurhayati, A. Analisis Potensi Lestari Perikanan Tangkap di Kawasan Pangandaran. Jurnal Akuatika Vol. IV No. 2. September 2013. Fakultas Perikanan dan Ilmu Kelautan Universitas Padjajaran. Bandung.

[10]. Saiful, Mulyadi, F. Mardin dan Husnawati. Analisis Risiko Finansial denganMetode Simulasi Monte Carlo. Prosiding Hasil Penelitian Fakultas Teknik. Group Teknik Mesin. Volume 7 : Desember 2013

[11]. Otoluwa, F. Tingkat Kesejahteraan Nelayan Buruh Pukat Cincin di Kelurahan Tenda Kota Gorontalo. Jurnal Ilmiah Perikanan dan Kelautan. Volume 1 Nomor 1, Januari 2015.

[12]. Thornton, P. K., P. J. Ericksen, M. Herrero and A. J. Challinor.Climate Variability and Vulnerability to Climate Change: A Review. Global change biology, 20(11), 3313-3328. 2014.

[13]. Sitompul, Z. dan E. Nurjani. Pengaruh El Nino Southern Oscillation (Enso) Terhadap Curah Hujan Musiman dan Tahunan Di Indonesia. Jurnal Bumi Indonesia, 2(1). 2013

[14]. Undang- Undang Republik Indonesia Nomor 7 Tahun 2006 Tentang Perlindungan dan Pemberdayaan Nelayan, Pembudidaya Ikan dan Petambak Garam

[15]. Peraturan Menteri Kelautan dan Perikanan Republik Indonesia Nomor 71/PERMEN-KP/2016 Tentang Jalur Penangkapan Ikan dan Penempatan Alat Penangkapan Ikan di Wilayah Pengelolaan Perikanan Negara Republik Indonesia.

[16]. Keputusan Presiden Republik Indonesia Nomor 12 Tahun 2020. Tentang Penetapan Bencana Non 
Alam Penyebaran Covid-19 Sebagai Bencana Nasional.

[17]. Keputusan Menteri Kesehatan Republik Indonesia Nomor HK.01.07/MENKES/382/2020

Tentang Protokol Kesehatan Bagi Masyarakat di Tempat dan Fasilitas Umum Dalam Rangka Pencegahan dan Pengendalian Covid-19.

[18]. Peraturan Pemerintah Republik Indonesia Nomor 21 Tahun 2020 Tentang Pembatasan Sosial Berskala Besar Dalam Rangka Percepatan Penanganan Covid-19.

[19]. Peraturan Menteri Keuangan Republik Indonesia Nomor 23/PMK.03/2020 Tentang Insentif Pajak Untuk Wajib Pajak Terdampak Wabah Virus Corona.

[20]. Peraturan Menteri Kelautan dan Perikanan Republik Indonesia Nomor 3/PERMEN-KP/20017 Tentang Organisasi Dan Tata Kerja Lembaga Pengelola Modal Usaha Kelautan dan Perikanan.

[21]. Peraturan Menteri Kelautan dan Perikanan Republik Indonesia Nomor 5/PERMEN-KP/2019 Tentang Perubahan Atas Peraturan Menteri Kelautan dan Perikanan Nomor 23/PERMENKP/2013 Tentang Pendaftaran dan Pendanaan Kapal Perikanan

[22]. Peraturan Menteri Perdagangan Republik Indonesia Nomor 33 Tahun 2020 Tentang Barang dan Persyaratan Barang Yang Dapat Disimpan Dalam Sistem Resi Gudang. 